\title{
Electra Complex and the Confusion of Albee's Martha's Sexual Identity: A Psychoanalytic Study
}

Arafat Abdali Rakhees ${ }^{1 *}$, Lajiman bin Janoory ${ }^{2}$

${ }^{1}$ Faculty of Languages and Communication, Pendidikan Sultan Idris university, Basra, Iraq

${ }^{2}$ Faculty of Languages and Communication, Pendidikan Sultan Idris university, 35900 Tanjong Malim, Malaysia

Corresponding Author: Arafat Abdali Rakhees, E-mail: alabbad.arafat@gmail.com

\begin{tabular}{|c|c|}
\hline ARTICLE INFO & ABSTRACT \\
\hline Article history & \multirow{9}{*}{$\begin{array}{l}\text { According to the Freudian psychoanalytic theory, earlier traumatic experiences highly influence } \\
\text { the psychological development of personality. Freud also affirms that the earlier years of } \\
\text { childhood development play a crucial role in the formation of personality. He states that all normal } \\
\text { infants go through specific stages of psychosexual development that are naturally progressive, } \\
\text { namely: oral, anal and phallic stages. Any disruption of or delay in the progress of any of the } \\
\text { psychosexual stages or failure to cope with them causes the fixation of the libido at a particular } \\
\text { stage. Martha, the central figure in Albee's Who's Afraid of Virginia Woolf?, suffered from painful } \\
\text { emotional experiences during childhood which gave her an unbalanced personality and a fragile } \\
\text { ego. She lived a lonely and troubled childhood because she was abandoned and rejected by her } \\
\text { father, a matter that has left a deep scar on her psyche. Martha also has a phallic fixation owing } \\
\text { to the unresolved sexual conflicts during the phallic phase of the psychosexual development, a } \\
\text { matter that negatively influences her personality. Applying Freudian psychanalytic theory, the } \\
\text { aim of this study is to investigate the influence of past traumatic experiences of childhood on } \\
\text { Martha's behaviour and her psychological wellbeing. The study also seeks to uncover the impact } \\
\text { of the unresolved Electra Complex on the development of Martha's personality and her sexual } \\
\text { maturity. }\end{array}$} \\
\hline Received: February 04, 2018 & \\
\hline Accepted: April 17, 2018 & \\
\hline Published: September 01, 2018 & \\
\hline Volume: 7 Issue: 5 & \\
\hline Advance access: July 2018 & \\
\hline Conflicts of interest: None & \\
\hline Funding: None & \\
\hline & \\
\hline
\end{tabular}

Key words: Who's Afraid of Virginia Woolf?, Freudian Psychoanalytic Theory, Martha, Phallic Fixation, Electra Complex, Defence Mechanisms

\section{INTRODUCTION}

Who's Afraid of Virginia Woolf? (1962) is Edward Albee's much-admired family drama that is cited as a powerful contemporary dramaturgical art of the twentieth century. It is considered a watershed in Albee's career for the success it scores, winning him eight prizes (McCarthy,1987). The play casts a light on the disastrous effects of the terrible relationship between the ineffectual, emasculated husband and his dominant and sexually concupiscent wife. It rotates around a dysfunctional marriage between George, the professor of History and Martha, the daughter of college president. The couple is childless and suffers from many psychological problems that are detrimental to their marriage. To survive their marriage and emotionally empty lives, George and Martha invent an imaginary child and play a fantasy of parenthood. In a night party to which the newly arrived biology professor, Nick and his wife Honey are invited, the couple releases their stored tensions and reveals scandalous secrets about each other.

In Albee's Who's Afraid of Virginia Woolf?, Martha is considered the hub around which the characters and the events of the play revolve. She serves as a psychic energetic force throughout the play. Martha is labelled by George as "the daughter of our beloved boss" and his "right ball" (p.24) who "plays the role of ball buster and castrating bitch" (Eby, 2007, p.603).

During an early childhood, Martha suffers from an emotional deprivation because of the death of her mother and an abandonment of her father. After her mother's death, Martha directs all her affection towards her father, but she fails to garner his attention. Martha's father neglects her and marries another woman, a matter that deepens her feeling of rejection and low self-esteem. Throughout the phallic stage of psychosexual development, Martha develops sexual attraction to her father and she experiences penis envy. As she fails to cope with the phallic phase successfully, Martha remains trapped in the phallic stage, resulting in what Freud terms as a phallic-fixation. This phallic-fixation disrupts her progress towards the next stages of psychosexual development and leads up to Electra Complex.

To resolve her Electra Complex, Martha suppresses her libidinal desires for her father and seeks a male spouse that compensates for her father's love and for the penis loss 
through conceiving a child. However, she neither finds a partner who is like her father, either physically or professionally, nor bears the male child that could resolve her Electra Complex since she is sterile. Thus, the unresolved Complex has an impact on Martha's sexual and emotional maturity, producing her phallic, narcissistic, masculine and sex-overindulging personality. Phallic- fixation also contributes to create her aggressive behaviour and confused sexual personality.

\section{A Girl in an Adult's Disguise}

Martha is depicted as a middle-aged woman in her fifties. She is "'a large, boisterous woman, looking somewhat younger, ample, but not fleshy." Martha is coarse, obscene, depraved, voluptuous. She is described as "'a spoiled and self-indulgent, wilful, dirty-minded and liquor-ridden" (p.83). Martha is also "'a devil with language" (p.10). She is intelligent, educated and keen, but her intellectual gifts are roofed with a brassy, aggressive, and vulgar facade.

Martha plays different feminine repugnant roles and has different personalities. She is painted as a sophisticated aristocrat of a social status and high powerful partner. She is the "destructive", "Voluptuous", "wicked", "monster", "'sub-human monster", 'Monstre!", 'Bête" and 'Putain!' female (Albee, 1962). Her dialogue is characterized by negative, hideous words and violent reactions especially she is drunk. For instance, she viciously attacks George, branding him as: "'beast", "'...A bog. A fen.G.D... swamp" (p.26).

One noticeable feature in Martha's character is her fear of loneliness and abandonment: "I am afraid George" (p.128). The reason for this fear has roots in her childhood. She is emotionally trapped in the history of her lonely childhood. She lost her mother early in childhood and grew up around her father. She tells Nick and Honey that: 'Mommy died early, see, and I sort of grew up with Daddy... I went away to school, and stuff, but I more or less grew up with him" (p.41).

Martha is a Daddy's girl. From her childhood, Martha has adored her father and spent much of her life trying to win his approval and get his attention. She expresses her fondness for her father to Nick and Honey saying, 'I admired that guy! I worshipped him... I absolutely worshipped him. I still do." (p.41). She esteems her father, fellows his example and obeys his commands in search for his love. For example, she invites Nick and Honey to a cocktail party because her father asks her to be kind to them:

GEORGE:... But why in God's name are they coming over here now?

MARTHA [in a so-there voice]: Because Daddy said we should be nice to them, that's why.

GEORGE [defeated]: Oh, Lord.

MARTHA:...Daddy said we should be nice to them.

GEORGE: But why now? It's after two o'clock in the morning, and...

MARTHA: Because Daddy said we should be nice to them! (p.4).

Martha's only power comes from her father. It is Daddy's power which keeps George on a tight rein. She gives more weight to her father's achievements. Most of Martha's speech is filled with admiration for him in a way that shows her feminine Oedipus attitudes:

MARTHA: Daddy knows how to run things (p.13).

MARTHA: Daddy was on this physical fitness kick... Daddy's always admired physical fitness... says a man is only part brain... he has a body, too' and it's his responsibility to keep both of them up... Daddy got the idea all the men should learn how to box... self-defense... Daddy's a strong man... And he asked George to box with him. Aaaaannnnd... George didn't want to... probably something about not wanting to bloody-up his meal ticket... Anyway, George said he didn't want to, and Daddy was saying, 'Come on, young man... what sort of son-in-law are you?'....and stuff like that (p.29).

However, Martha fails to gain her father's affection. Therefore, she feels disappointed and looks for her love object and role model in another man. Martha first married a gardener, but when her father, the president of the college, found out that she married beneath her, he annulled that marriage. She remarks: 'Daddy and Miss Muff got together... put an end to that... real quick...annulled" (p.42). So, Martha returns to her Daddy's home as a hostess and a caregiver: 'I came back here and sort of sat around for a while. I was hostess for Daddy and I took care of him" (p.42).

Martha is craving love. To obtain her Daddy's affection and respect, she marries George who works in academia and is also preoccupied with History like her father, aspiring that he will occupy her father's place as the president of university. She directs her attention to George and exerts much effort to make him a replica of her father's character. Martha explains her reasons for marrying George in her conversation with Nick:

MARTHA: I was sort of on the lookout, for... prospects with the new men. An heir-apparent. And I got the idea, about then, that I'd marry into the college... Daddy had a sense of history... or... continuation. history... and he'd always had it in the back of his mind to... groom someone to take over... some time, when he quit. George "'came into... the History Department" (p. 42-43).

Additionally, Martha selects George as a spouse in order to make up for the love her father could not give to her and fill in the emotional void caused by his neglect and rejection. She, moreover, hopes that George will provide her with the power she desires. However, she gets none and she ends up as a castrated object. However, George does not nurture her ambitions for he is not the high-flyer that would achieve Martha's dreams or even gratify her Daddy. In fact, Martha's marriage to George is obviously motivated by an infantile wish to please her Daddy and, in return, gains his attention and wins his approval. This reveals her unconscious sexual motives and traumatic self. Martha lacks a sense of selfworth and a positive self-image, then in her choice of George she is fascinated by what she could be through his assistance. She sees in her mind's eye that George someday will help her stand courageously in front of her father. Her main interest is to marry a man who could make her look remarkable and vital in her father's eyes. But, Martha's dream is more 
real to her than George who seems to have a different plan for the future. He misunderstands the little kind girl lying behind the old vicious Martha:

GEORGE:... we get misunderstood Martha, the good-hearted girl underneath the barnacles, the little Miss that the touch of kindness ' $\mathrm{d}$ bring to bloom again (p.83).

\section{Martha's Psyche in Terms of Freudian Psychoanalysis}

Freud $(1953 ; 1963 a)$ explicates that psychological development in childhood takes place in a sequence of fixed overlapping psychosexual stages that all human infants should experience: "oral, anal, phallic, latency, and genital." And each one of these stages is linked with a specific conflict that needs to be resolved before the individual can successfully proceed to the following stage. Further, in each stage, the child derives pleasure from a certain erogenous zone. Freud $(1953 ; 1963 a)$ emphasizes that personality is generaly established by the age of four or five. So, early experiences play a key role in the development of personality and have a marked impact on the behaviour of person in future life. During the childhood stages wherein the libidinal drives of the id concentrates on a certain erogenous area. Freud affirms that if the psychosexual stages are negotiated and passed successfully, this will produce a normal and balanced personality. If problems are not resolved at a particular stage, fixation can result and a person will be locked in this stage till the hindering conflicts are resolved.

One of the psychosexual stages that plays a vital role in forming an individual's personality is the phallic stage which paves the way for the individual's sexual maturity and his/ her normal heterosexual life. Throughout this stage, boys are unconsciously attracted to their mothers and experience Oedipus Complex while girls have sexual desires for their fathers. They feel penis envy and see their mothers as rivals, suffering from Electra Complex. In order to resolve this complex and goes through this stage successfully, the girl identifies with her mother and represses her sexual feelings toward her father. They wait for an alternative father-figure in a partner who resembles her father in character or profession and also endows her with a male child, thus metaphorically earning a penis. Freud (1953) posits that fixation at the phallic stage develops a phallic character.

Martha has developed unconscious sexual attraction to her father. She idealizes her dad as the object of her desire and reveres him as a figure of strength and power in her life. She keeps on looking for a father figure in a future spouse who looks like her dad physically or professionally. Martha ends up repressing her affection towards her father and seeks a socially acceptable sexual relationship by marrying George, an academic scholar that resembles her father professionally. Indeed, Martha finds alternative sources of her phallic obsession not only in George, but also in other adulterous relationships.

By choosing George as a love-object, Martha intends to reproduce the archetypal father-figure through him. However, George refuses to become the fulfillment of Martha's ambitions, a matter that affects her psyche, causes her a psy- chological disorder and renders their marriage dysfunctional. Post (1969) refers to this fact, saying that since Martha suffers from Electra Complex, she marries George in the hope that he will be a "lover-father" figure to her (p.58).

Actually, the issue with Martha is more complex. She has lost her mother in her early childhood, therefore she has no rivalry for her father's affection. Hence, Martha focused all libidinal energy on her father and directed all her interest towards him. Rather than being affectionate her, Martha's father sends her to convent and marries another woman. He was indifference to the suffering of his daughter as mentioned by George: "Poor weighed-down girl, PLUS a father who really doesn't give a damn whether she lives or dies, who couldn't care less what happens to his only daughter" (p.120). As a result, Martha neither passes the phallic stage successfully, nor satisfies her emotional needs normally. Her frustration at the phallic stage ensues a subsequent disruption to her normal personality development. Dobie (2011) argues that "'if childhood needs are not met, the adult is likely to suffer arrested development. The mature person may become fixated on a behaviour that serves to fulfill what was not satisfied at an early age" (p.58). Because her sexual desires for her father are not satisfied, Martha has a phallic fixation which renders her a phallic character.

Feelings rejected and abandoned by her father, Martha has a negative self-image. She is afflicted with self-disgust, self-doubt and experience feelings of inferiority. She herself admits that in self-revelation in Act III: 'I disgust me. I pass my life in crummy, totally pointless infidelities. (Laughs ruefully) would-be infidelities" (p.100). Martha's feeling of low self-esteem is at the center of the obscene and aggressive behaviour she exhibits throughout her adult life. Although she is the apparent heir to a university's president, Martha has never thought of taking over her father's position because she lacks self-confidence. Freud asserts that 'feelings of inferiority arise when the ego is unable to meet the superego's standards of perfection" (Feist and Feist, 2009, p.30). Accordingly, Martha feels inferior because her ego is unable to meet the professional and moral standards of her father who represents the superego.

Based on Freud psychosexual stages theory (1953), the satisfactory parental behaviour and resolving of the Electra Complex plays a critical role in the developing of the superego. That is, in identifying with the opposite sex parent, the child internally adopts the moral values of his parent and forms his ego-ideal or the superego. Since Martha's Electra Complex is unresolved, entailing her superego has not formed yet. She is still in quest for her ego-ideal. This entails her immoral behaviour and her atypical personality. Having been locked in the phallic-stage, Martha is turned into a possessive and domineering woman who continually tries to control men. She is functioning as a seductive and promiscuous woman.

Freud (1953) stresses that an Oedipal conflict has an emotional impact on girls more than boys. The woman's loss of the phallic symbol makes her self-doubt. So, the woman tries to gain power by governing men either through seducing them, or through pretending to have a high self-confi- 
dence. Given that Martha is inflicted with a phallic-stage obsession, she develops into a phallic woman with self-assured, inconsiderate and narcissistic Earth Mother. For about twenty- three years, Martha dominates the scene and keeps George under her sway. She emasculates and castrates him, questioning his manhood, a matter that precipitates the failure of her marriage and its dysfunctionality. Martha also flirts with Nick and has an affair with him:

MARTHA: Hey... hand me a cigarette... lover. [Nick fishes in his pockets.] that's a good boy. [He gives her one]Unh... thanks.

[He lights it for her. As he does, she slips her hand between his legs, somewhere between the knee and the crotch, bringing her band around to the outside of his leg.]

[He seems uncertain, but does not move. She moves her hand a little.]

Now, for being such a good boy, you can give me a kiss, C'mon (p.86).

Leading a double life, Martha personality is unbalanced. She suffers from an internal struggle between her repressed attraction to her father and the liberation of her libidinal drives. She has not left behind Daddy and the prospect of his unconditional love though she got herself involved in many erotic adventures. Martha's promiscuity is triggered by George's inability to replace her father. Further, she feels bitter about George's failure to win her father's endorsement, fulfilling the childish ambition of the id and compensates psychologically for the loss of ego ideal. To accept George as he is, Martha must relinquish the possibility of her father's love forever.

\section{Martha's Regression to Childhood}

Martha is characterized by her temporal regression to earlier stages of childhood development. She sometimes behaves, as George describes her, like "'a misunderstood little girl" (p.119) who is 'a naive at heart" (p.74). Martha's puerile behaviour can be seen in her speech with George wherein she imitates kids' talks and conducts:

MARTHA: Ha. ha, ha, HA! Make me another drink... 'lover.

GEORGE: [taking her glass]: My God, you can swill it down, can't you?

MARTHA [imitating a child]: I'm firsty (p.7).

The childlike behaviour of Martha can be analyzed in terms of regression theory. According to Freud (1963a), regression is an unconscious defence mechanism which a person resorts to in order to cope with stressful situations or whenever he is caught in a problem or suffers from anxiety. Freud defines regression as the temporary or permanent relapse of the ego into a former stage of infantile development or earlier patterns of behaviour to avoid dealing with unacceptable desires or self-induced conflicts. Regression is sometimes considered a healing process whereby traumatic experiences and past memories buried deep in the recesses of the unconscious are given vent through a childlike behaviour (Kernberg, 2004).

Hence, Martha's regression to a girlish behaviour is a desperate attempt to defend her ego against the troubles and pains of her unhappy marriage. She acts as a child by throwing a tantrum and playing vicious childish games and baby talk. Reverting to an earlier stage of development manifests itself in Martha's juvenile games and pathological fantasies where primitive methods of psychic expression are employed. Further, she uses facial expressions, verbal abuses and obscene jokes. Martha's inner child works and resorts to regression whenever she feels neglected by George or when she wants to relieve her emotional tension. A clear example of Martha's regressive behaviour and babyish talk is seen in her exchange with George:

GEORGE: I wish you'd tell me about something sometime... I wish you'd stop springing things on me all the time.

MARTHA: [friendly-patronizing]: Oh, George! GEORGE: Always.

MARTHA: Poor Georgie-Porgie, put-upon pie!

[As he sulks] Awwwwww... what are you doing? Are you sulking?

Hunch ? Let me see... are you sulking? Is that what you're doing?

GEORGE [very quietly]: Never mind, Martha...

MARTHA: Awwwwwwwwww!

GEORGE: Just don't bother yourself...

MARTHA: Awwwwwwwwww Hey! (p.5).

Just like an immature child, Martha has ambivalent feelings towards George. She behaves paradoxically and her emotions seesaws up and down. She manifests opposite feelings simultaneously. Sometimes, she shows her disgust and hate for George: 'You make me sick, you miserable, a bastard" (p.80-81). Other times, she confesses her feelings of love for him:

MARTHA: There is only one in my life who has ever... made me happy. Do you know that? One!

NICK: The... the what-do-you-call-it? ...uh...the lawn mower?

MARTHA: No; I'd forgotten him... Hunh. No; I didn't mean him; I meant George, of course.Uh. George; my husband (p.111).

From Freud's perspective (1953), the reason for Martha's ambivalent feelings towards George can be traced back to the oral stage of psychosexual development. Throughout this phase, the child obtains his/her sexual pleasures from sucking his/her mother's breast. S/he begins discovering the world around him or her either by gripping objects or putting them in his/her mouth to suck or bite them. The child becomes interested in both libidinal and aggressive desires and loves as well as hates his/her mother's breast at the same time. That is, the child has ambivalent feelings and $s / h e$ is not sure whether to bite or suck his/her mother's breast. As a result, Martha displays an Oral Personality.

Freud (as cited in Houston, 2005) adds that fixation at the oral phase arises from the excessive or insufficient gratification. People who suffer from an Oral Fixation will drive their pleasure in adulthood from oral activities such as "'overeating, smoking, drinking and kissing" or from "chewing objects and nail-biting. They also become sarcastic and critical. Freud refers to such people as 'oral-aggressive or oral-sa- 
distic" (p.296). Martha loses her mother at early childhood which means that her oral pleasures are not satisfied sufficiently. So, Martha is stuck in the Oral stage of psychosexual development. This issue affects her behaviour later on in life. In order to gratify her libidinal desires in adulthood, Martha has a stronger tendency to smoke, drink and kiss. She is too characterized by her sarcastic, critical and aggressive personality. And like a nervous child, she is sucking and chewing ice cubes in her drink like a child:

MARTHA: Hey, put some more ice in my drink, will you? You never put any ice in my drink. Why is that, hunh?

GEORGE: I always put ice in your drink. You eat it, that's all. It's that habit you have..., chewing your ice cubes., like a cocker spaniel. You'll crack your big teeth (p.6).

\section{Martha's Narcissistic Personality}

Martha is a narcissistic, self-absorbed and egocentric woman. She has an exaggerated feeling of self-importance and excessive need for admiration. While she rises herself to the position of an ideal self-image of Earth Mother, Martha belittles George and Nick, degrades them to the status of a flop. She narcissistically draws attention to herself: 'You're all flops. I am the Earth Mother, and you're all flops" (p.100). According to Martha, George is a flop because he is passive and lacks the persistence crucial to a successful career. Likewise, Nick is a flop since he renders himself impotent and fails to satisfy her sexual desires.

Freud (1957) declares that the female who fails to manage the sexual problems of the phallic phase will turn into a phallic character and self-centered person characterized by recklessness, self-possession, narcissism, futility and vanity. Besides, this will result in a homosexual individual who is unable to love, but himself. Freud (1957) says that while females cross the phallic stage to maturity, they recognize their bodies and begin to focus on their individual needs which lead to an "intensification of the original narcissism" especially if women are beautiful. This will provide them with a feeling of happiness, satisfaction and intensify their love for themselves. Freud mentions that women need to be loved and "the man who fulfils this condition is the one who finds favour with them" (p.88-89).

Albee (1962) portrays Martha as "'a large, boisterous woman, looking somewhat younger, ample, but not fleshy." That is, she is both attractive and strong woman. Martha is proud of her strength and beauty. She constantly shows off her good looks to gain admiration, satisfaction and bolster up her self-confidence and narcissism. For example, she appeals to Nick by changing into a seductive clothing:

MARTHA [entering]: what sort of talk?

[MARTHA has changed her clothes, and she looks, now, more comfortable and... this is most important... most voluptuous]

GEORGE: there you are, my pet.

NICK [impressed; rising]: Well, now...(p.24).

In selecting George, the man whom she loves and is loved by him, as her love object, Martha does not only gratify her libidinal drives, but also feeds her narcissism. Kernberg (2012) states that a woman loves a man who loves and is psychologically dependent on her because such a man 'feeds her narcissism and protects her" (p.138). Considering the idea from this angle, Martha's love for George could be seen as a form of narcissism. Being unable to bear a child that feeds her narcissism, Martha attempts to realize her dreams and survive her lost self through George. She is seeking in George the narcissistic ideal she desired to accomplish in her childhood when she felt herself masculine and she followed that line of development till she reaches feminine maturity that interrupts the development of this ideal. Martha is still yearning for a masculine ideal which is, in truth, a continued existence of the childlike nature she once displays herself (Marković, 2000).

Martha's narcissism is further displayed in her reciting of the qualities of her imaginary son. She attributes most of the personality traits of the illusory son to herself, incorporating in him all her dreams of the ideal childhood and familial bliss. Linda (1987) remarks that for the infertile, the fantasy child "offers an opportunity to "re-do" their own childhood... marred by emotional abandonment or exploitation. They look to parenting children of their own as an opportunity to correct and re-balance the family ledger" (p.362). In reality, this is derived from Martha's need for 'self-preservation" as expressed by Freud (1957) who sees narcissism as "the libidinal complement to the egoism of the instinct of self-preservation" (p.74). Thus, the process of imagining an illusory baby could be viewed narcissistically because in inventing the legendary son, Martha wants to relive her own childhood. She has a narcissistic, unconscious desire to perpetuate her self-image in the fantasy son and realizes her youthful ambitions and hopes through him. Freud (1957) reports that " the child shall fulfil those wishful dreams of the parents which they never carried out" (p.90).

MARTHA [to GEORGE]: Our son does not have blue hair. or blue eyes, for that matter. He has green eyes... like me.

GEORGE: He has blue eyes, Martha.

MARTHA: (determined) Green.

GEORGE: (patronizing) Blue, Martha.

MARTHA: GREEN! He has the loveliest green eyes... they aren't all flaked with brown and gray, you know... hazel... they're real green... deep, pure green eyes... like mine.

NICK: (Peers) Your eyes are... brown, aren't they?

MARTHA: GREEN! (A little too fast) Well, in some lights they look brown, but they're green. Not green like his... more hazel (p.39-40).

Freud (1957) says that children serve as a means by which a person attempts to recover his/her lost egotistic perfection and 'self-love' that he/she enjoys throughout childhood by reproducing a new love object. Accordingly, narcissism is a nostalgic survival of the lost self, a sheer pride, a selflove characteristic. Martha's assertion that her son's eyes are green like hers also "reflects her psychological desire to be biologically close to her offspring" (Prugh, 2014, p.63). Based on Freud's ideas about narcissism, Martha's relation 
with her unreal son is pathological. She interchanges herself with the imaginary son whom she loves and revives her narcissistic ego through him. In Freud's words (1957), 'parental love is nothing but the parent's narcissism born again which is transformed into object-love, unmistakably reveals its former nature" (p.91). Supporting this view, Albee (as cited in Gross, 2009) claims that:

Every child is an imaginary construction, the projection of narcissistic impulses. It is a marker that serves to characterize reproductive, genital sexuality as meaningful and thus stigmatize all other sexuality as meaningless. As a result, this narrative of loss can be seen more specifically as a loss within a particular ideological construction of sexuality (p.124-25).

Additionally, by inventing an imaginary son rather than a girl as her fantastic child, Martha attempts to compensate for her loss in the imaginary son who has the penis which the girl lacks: "'A son who I have raised as best I can against. vicious odds, against the corruption of weakness and petty revenges" (p.121). The son of dreams is an external self-representation into which Martha projects her wishes that need to be satisfied, anxieties that need to be handled and fears that need to be overcome. Her love for the illusory child is actually a displaced self-love. Freud (1919) describes this performance of the narcissist as "an insurance against destruction of the ego" (p.235). Through the unreal son, Martha covers and simultaneously displays at a safe distance the longings and crises hindering her own advance towards identity as a normal adult:

MARTHA: Our child. (With great sadness) And we raised him... (Laughs, briefly, bitterly) yes, we did; we raised him. And as he grew... and as he grew... oh! so wise!... he walked evenly between us. [She spreads her hands.]... a hand out to each of us for what we could offer by way of support, affection, teaching, even love. and these hands, still, to hold us off a bit, for mutual protection, to protect us all from George's... weakness... and my. necessary greater strength... to protect himself... and us (p.118).

Martha's make-believe motherhood of can be interpreted in terms of psychoanalytic theory. Martha is psychologically abnormal and unaware of her homosexuality. In her choice of the imaginary son to be her love object, Martha indeed chooses to love herself since she treats the child as her ego. Freud (1957) asserts that "for narcissistic women. there is a road which leads to [a] complete object-love. In the child which they bear, starting out from their narcissism, they can then give complete object-love" (p.89-90). Hence, Martha's attraction to the imaginary child expresses not only admiration for herself, but a pathological behaviour to sexually possess herself. She suffers from 'the narcissistic personality disorder" which Kohut (1977) attributes to the "defects in the psychological structure of the self" originated in early childhood (p.3).

Freud (1957) thinks that the parents' love for their children is narcissistic because it stems from their love for themselves and their desire to maintain and reproduce the earlier narcissistic version of themselves through their chil- dren. Following Freud's example, Kohut (1977) refers to the dysfunctional parental relationship as a form of narcissism. He says that the child serves as a therapeutic means that provides the parents with love, happiness and attention- the psychological needs they have they have not satisfied before. The Narcissist uses a parent-child relationship to compensate for the familial love $\mathrm{s} /$ he has never received from her/ his parents in childhood. Then, Martha's love for her imaginary son comforts her and makes her feel good about herself. She attempts to make up for the loveless relationship with her father and compensates for the attention she has never received from him during childhood which has a negative impact on her life as an adult.

Furthermore, The fantastic son offers Martha an idealized version of a virile young man she admires and wishes to be. She too sees in him the mirror image of her own self and the phallus she unconsciously desires to have. Freud (1964) explains that penis envy usually implies a girl's desire to be a boy. The girl's wish continues to transform into childbearing and finds expression in the act of giving birth to a boy. As such, Martha's love for the imaginary child is an alternative manifestation of penis envy as well as a penis substitute.

\section{Martha's Masculinity}

Martha is an androgynous woman. She does not have a distinct identity as she plays the gender roles of both sexes. Martha is neither masculine nor feminine whether in appearance or in behaviour, hence she displays the personality traits of both women and men. She is presented as a manly woman in her demeanors and conducts, disguised in woman's garments: 'I'm loud, and I'm vulgar, and I wear the pants in the house because somebody's got to" (p.83). Martha's loud voice, vulgarity, coarse humour, lascivious talk, "braying" laugh and officious manner manifests her masculinity. Kelly (1990) declares that "in her appearance and behaviour, Martha is mannish and transgressive" (p.373). Denying her feminine identity, Martha assumes a male register, moving up to a male equivalent.

From the beginning of the play, Albee gives the impression that Martha is a man more than a woman, drawing her as a "large, boisterous and ample" which are masculine rather than feminine qualities. Her male-like toughness is as well verified through George's description of her dance with him: "'Martha had her daguerreotype in the paper once oh, 'bout twenty-five years ago. Seems she took second prize in one o' them seven-day dancin' contest things... biceps all bulging, holding up her partner" (p.67). Further, the masculine behaviour of Martha finds release in her interest in boxing wherein she swings at George's jaw and knocks him down with boxing-gloves:

MARTHA:... George and I had this boxing match... Oh, Lord, twenty years ago... a couple of years after we were married.

NICK: A boxing match? The two of you?

HONEY: Really? (p.28).

MARTHA:...and George wheeled around real quick, and he 
caught it right in the jaw.... and he was off balance... he must have been.... and

he stumbled back a few steps, and then, CRASH, he landed

... flat... in a huckleberry bush! (p.30).

In addition, Martha's masculine inclination is revealed through her libidinous behaviour. She is described as a "powerful and sexually concupiscent" (Wolfe, 1965, p.120). Sexual desire, as Freud (1953) puts it, is a masculine privilege. He says "libido is invariably and necessarily of a masculine nature (p.121). Further, LoPiccolo and Heiman (1978) claim that a frequent sexual intercourse is socially considered a characteristic of men while women are expected to be submissively interested in sex. So, the woman who is more interested in sex than the man, is seen as "masculine or, worse, polymorphous perverse" (p.54-55).

Actually, Martha's masculinity feeds on George's impotence. It emerges because of his passive and feminized position, deviation from the masculine gender role and abdication of responsibility. Though Martha overly flirts with Nick in the kitchen, George responds apathetically to their dalliance. When he asks her if she really copulates with Nick, Martha replies: ''truth or illusion, George. Doesn't it matter to you... at all?" (p.109). According to Dukore (1965) 'the sexual roles of George and Martha are hermaphroditic (p.264). George's feminine attitude motivates Martha to emasculate his manhood and act as the sole male of the house. She castrates and demeans George in Nick's presence, referring to his metaphorical loss of the phallus:

MARIHA: maybe Georgie boy didn't have the stuff... didn't have much... push... In fact he was a sort of a... a FLOP!

GEORGE [still with his back to them all]: Stop it, Martha.

MARTHA [viciously triumphant]: The hell I will! You see, George didn't have much push he wasn't particularly aggressive. In fact he was sort of a. [Spits the word at George 's back]... a FLOP! A great. big “ fat... FLOP! (p.45).

Nazerzadeh Kermani (as cited in Falsafi et al, 2011), states that both women and men bear the qualities and characteristics of each other because they live together, a matter that makes men internalize the behaviours and attitudes of women who in turn may expose masculine tendencies. He says "'humans are basically bi-genders" and adds that while ' 'the woman's psyche comprises the male aspects, the man's psyche comprises the female aspects" (p.1000). On the other side, Freud (1957) mentions that there are men who deviate from the masculine line and follow the "female path" and women who reject their femininity and follow the "male path." Hence, Martha's masculinity is an expression of her penis envy and refusal of the female role.

Hauge (2009) claims that due to her feminine and masculine behaviours, Martha can be classified either within the male gender category as a homosexual in woman drag or within the female gender category as a voluptuous woman who seduces men. The ambivalence about Martha's identity is linked with 'the doubt of the presence or absence of a pe- nis and to the disavowal of object loss" (Blum,1969, p.893). That is, Martha sometimes adopts a masculine behaviour, denying unconsciously the absence of the phallus. At other times, she seems feminine in her seductive dress and sexual behaviour. Deep down, Martha refuses to be a castrated object. She pines for the masculine image she once has had during childhood before it is interrupted by the maturity line since 'girl's sexuality starts as masculine phallic (Freud as cited in Hayman, 2013, p.6). To explain, Martha's masculinity is her nostalgic wish to regress to the pre-oedipal stage of her development when she felt a masculine. She is still obsessed with her penis loss and her mannish behaviour is a manifestation of her phallic fixation. This too reflects Martha's unresolved Electra Complex and her overwhelming desire to possess her father, thus have the penis. LoPiccolo and Heiman (1978) say that women's masculine conduct reflects their preoccupation with lost object or "'a fixation at some pre-genital level of development" (p.55). In this regard, Freud (1957) provides an explanation:

There are... women who do not wait the child to cross the stage of "'narcissism to object-love." Before physical maturity, they feel masculine and develop some way along masculine line; after this trend has been cut short on their reaching female maturity, they still retain the capacity of longing for a masculine ideal which is in fact a survival of the boyish nature that they themselves once possessed (p.90).

Owing to the unsuccessful negotiation of the Electra Complex, Martha is mentally unstable and emotionally immature. She is swaying between femininity and masculinity. She stands at the dividing line between her desire to be like her father and have a penis, or to be a castrated female. Martha played the feminine daughter and hostess in her daddy's house, but now she acts both as the patriarchal role of the male as well as the heterosexual role of the wife in her husband's house. For Martha to have a penis means to be physically complete and to be socially esteemed, loved and respected. So, to compensate for the loss of the phallus, Martha plays the role of the belligerent male she inherited from her father and "wears pants in the house because somebody's got to" (p.83).

By assuming a masculine role, Martha transcends the social limits and departs from her female identity. From Freudian viewpoint (1963a), Martha, in her transgressive actions appears as the girl who "'may refuse to accept the fact of being castrated, may harden herself in the conviction that she does possess a penis and may subsequently be compelled to behave as though she were a man" (p.188). Martha refuses to play the role of the subordinate and she often elevates herself to the a superior status: 'I am the Earth Mother, and you're all flops" (p.100). She rebels against the role of a passive subject and she chooses to be the omnipotent "phallic mother" who rejects heterosexuality and wishes to revert nostalgically to the pre-oedipal homosexual desire of the mother (Gilchrist, 2011, p.858).

In short, Martha acquires a dual personality. She is playing a double role: the male and the female. The male part of her serves to satisfy the quest for penis in the female part of 
her. In order to break the circle of the phallic-fixation with her father, Martha seeks an alternative phallus by assuming the masculine role. Thus, she fulfills her hidden desire of possessing her father.

\section{Martha's Sexuality}

Albee sketches Martha as a vivacious, promiscuous and highly sexual character who is mainly concerned with satisfying her sexual urges. Martha is exposed as an adulterer by Nick who labels her as an "aimless. wanton" (p.104), as well as George who calls her a "SATANIC BITCH" (p.72) and "the only true pagan on the eastern seaboard [who] paints blue circles around her things (p.37). Martha is a pervert and her sexual appetite is the motivating force behind her erotic behaviour. In Martha's view, to be a real and powerful, a woman should be an overtly sexy and rely primarily on sexiness to attract men. Gilchrist (2011) argues that for Martha, 'sex and power are the crux of the matter" (p.855). Martha has a penchant for having sex with handsome young men. She has the energy and sex appeal of a woman half her age and she still aches for the intimacy and sexual contact of marriage. Freud defines female sexuality as "abnormal and immature" behaviour (LoPiccolo and Heiman, 1978, p.54). Then, Martha's deviant behaviour and obsessive desires categorize her as abnormal. Her sexuality is shown in her conducts and couched in her figurative language laden with sexual insinuations:

MARTHA: Hello. C'mon over here and give your mommy a Big sloppy kiss.

GEORGE:... oh, now...

MARTHA: I WANT A BIG SLOPPY KISS ! (p.7).

MARTFIA: You're a scientist, aren't you? C'mon ... make an experiment, Experiment on old Martha.

NICK [giving in]:...not very old...

MARTHA: That's right, not very old, but lots of good experience... lots of it.

NICK: I'll. I'll bet.

MARTHA [as they draw slowly closer]: It'll be a nice change for you, too (p.86-87).

In psychoanalytic theory, Freud hypothesizes that the structure of the mind involves three parts: the id, the ego and the superego. Id is defined as the unconscious inner child of personality which "'serves the pleasure principle." It continually seeks to gratify its desires regardless of demands of the ego and the restraints of the superego. Id does not change, but its Infantile impulses remain dynamic and continue from childhood to adulthood (Feist and Feist, 2009, p.27). A person who constantly strives to satisfy his libido is counted as a pleasure-seeking person dominated by the id. Martha, in her pleasure-seeking manners, is a lifelike representation of the id. She is a self-servant to the aggressive and sensual impulses of her id. Martha acts out sexual escapades with many men and her seduction of Nick exposes her sexual charisma. Domineering, Martha is sexually active at a young age, choosing a partner for herself, but her father has her marriage annulled since it is unacceptable for a woman within her social milieu to be a sexual. Here, Martha's father functions as the superego which suppresses the urges of the id.
Martha's eroticism is acknowledged by George. He tells Nick that the way to the promotion in his career and status in the university is through having sex with the wives of the faculty. George implicitly encourages Nick to make advances at Martha:

GEORGE: Now that, sit! you can take over all the courses you want to, and get as much of the young elite together in the gymnasium as you like, but until you start ploughing pertinent wives, you really aren't working.

NICK: yeah... I know.

GEORGE: And the women around here are no better than puntas-you know, South American ladies of the night. You know what they do in South America... in Rio? The puntas. Do you know? They hiss... like geese... They stand around in the street and they his: ar"1ou... like; bunch of geese.

NICK: And I'll bet your wife's the biggest goose in the gangle, isn't she. ? Her father president, and all.

GEORGE: You bet your historical inevitability she is!

NICK: Well now, I'd just better get her off in a corner and mount her like a goddam $d o g$, eh?" (p.60-61).

Eventually, George goes as far as accusing Martha of molesting their imaginary son, telling their guests: "our son ran away from home all the time because Martha here used to corner him. He used to run up to me when I'd get home, and he'd say, Mama's always coming at me" (p.64). In another occasion, George dubs Martha's mind as 'the mind's blind eye" in reference to the id which drives Martha to gratify the sexual desires and whims of her libido blindly for "the heart's ease":

GEORGE: [brings MARTHA her drink] pure and simple... here you are, angel]... for the pure and simple.

[Raises his glass] For the mind's blind eye, the heart's ease, and the liver's craw (p.11-12).

Blinded by her libido, Martha indulges herself in sexuality to satisfy the instinctual drives of the id. One reason behind inviting Nick and Honey to a night party is to have her sexual passions for Nick satisfied through having intercourse with him. She dresses up seductively, lures Nick to commit adultery with her. She makes a cuckold of George, unfolding exciting stories about her past sexual experiences. "'Martha is the engine, she is also the director, positioning both men for a drama she will control" (Davis, 1994, p.224). Yet, the sex act is not consummated since Nick could not gratify Martha's libidinal drives and he proves himself impotence. Feeling frustrated, Martha releases her unfulfilled desires via sarcastic remarks and speech full of reproach for Nick, depicting him as a failure (Falsafi et al, 2011).

NICK: I' m sorry. You're disappointed. You should try me sometime when we haven't been drinking for ten hours, and maybe....

MARTHA[still braying]: I wasn't talking about your potential; I was talking about your goddamn performance.

NICK[softly]: Oh.

MARTHA[she softer, too]: Your potential's fine. It's dandy.[Wiggles her eyebrows]. Absolutely dandy. I haven't seen such a dandy potential in a long time. Oh, but baby, you sure are a flop (p.100). 
In an attempt to resolve her phallic-oedipal conflict, Martha wallows in several extramarital affairs with young men. She seeks in her sexual perversion a protection against a tortured ego. Her marriage to George and her sexual relationship with Nick is to compensate for the father she misses and for the phallic loss. Martha's sexual excursions are also protests that arise from the repression and muting exercised by society. She is driven by this never-satisfied sexual desire which her marriage fails to quench. Martha plays out sexual fantasies in order to escape reality and reduce anxiety caused by feeling guilty. She transforms her erotic act with Nick into a performance that serves to protect her self-image guard against any punishment that her superego might exact on her.

Martha is disappointed in her life because her fate is tied to the only man she acknowledges, namely, her father. As a denial of the harsh reality, she takes refuge in fantasy, alcoholism and sexual expeditions to live in a state of suspended animation. But it seems that "'like Virginia Woolf, Martha never escapes herself, her cage" (Weales, 1975, p.15). Accordingly, Martha is afflicted by psychological and neurotic problems. Freud emphasizes that most psychological problems have a sexual background. He views sex as "'a dangerous force, one that society had to channel (or sublimate) into work and/or monogamous bonds" (LoPiccolo and Heiman, 1978, p.52). Feeling marginalized and abandoned by her father, Martha gives free reins to her sexuality which, in its turn, allows her to have power and self-worth. From Malarvizhi's standpoint (2013), Martha's sexual behaviour stems from her feeling worthless and unlovable. She prostitutes herself because she feels dirty, nasty and mean. To establish her identity, as a sexually attractive female, among the male circle and to subjugate them, Martha utilizes her feminine charms. And by so doing, she holds sway over George as well as gains an aura of supremacy over phallic power.

In Who's Afraid of Virginia Woolf, sexuality is employed as a secret weapon to gain authority, physical superiority, self-actualization, subjectivity and gender identity. Paolucci (1972) states that in this play, "sex is the dynamo" (p.46). Martha revolts against the conventional/orthodox gender image expected by the American society in the nineteen sixties and transforms into a rebellious prostitute. She uses her sexual promiscuity as a bait to lure, castrate and govern Nick and to undermine and deflate George in order to establish her identity as a sexual subject. Nevertheless, she misses the mark since "'by putting her sexuality out in the open, she is not able to achieve power, but rather reduces herself to a sexual object to the two males" (Hauge, 2009, p.26).

Martha is not the only one who profits from indulgence in sexual adventures. Both Nick and George have their own personal gains. Nick uses sex to achieve his ambition and climb the ladder of success: "I'd sort of insinuate myself generally, play around for a while, find all the weak spots. start some special groups for myself. plough a few pertinent wives" (p.59-60). By the same token, George gives Nick the permission to have sex with Martha to prove his own masculinity and Nick's impotency: ' If you're a houseboy, baby, you can pick up after Me; if you're a stud, you can go protect your plough. Either way. Either way" (p.109). As a result, Martha becomes the pivot around which the two men move with sex as the main motive for the characters' conducts. Davis (1994) says that Martha operates as the prime mover and instigator who fuels "male bonding" and spurs " phallic competition" between George and Nick (p.221).

According to Freud (1963b) women's fetish for sexual pleasure is stronger than men's. He attributes woman's perverted behaviour and lack of morality to the anatomical structure of her body. Freud (1963b) thinks that woman's psyche is influenced by her physiological nature. Unlike men who have a moral superego due to their phallic object and negotiating successfully with their Oedipal complex, women do not. Given that women are under the control of the unbridled sexual drives of the id, they are unable to repress their ephemeral urges or emotional energy. Freud confirms that:

For women the level of what is ethically normal is different from what it is in men. [...] Character traits which critics of every epoch have brought up against womenthat they show less sense of justice than men, that they are less ready to submit to the great necessities of life, that they are more often influenced in their judgments by feelings of affection or hostility - all of these would be accounted for by the modification in the formation of their superego (p.193).

Martha's debauchery is viewed in the sensual indications underlying her traditional cants:

MARTHA: You have a poetic nature, George... a Dylan Thomas-y quality that gets me right where I live.

GEORGE: Vulgar girl! With the guests here! (p.12).

GEORGE: Why don't you go back to your necking and stop bothering me? I want to read.

MARTHA: Why, you miserable... I'll show you.

GEORGE: No... show him, Martha... he hasn't seen it (p.91).

In the preceding exchange, George deliberately misconstrues Martha's sentence and exposes her libido. He interprets "it" as an allusion to her genitalia which she plans to show to Nick to seduce him. He labels Martha 'vulgar' because he realizes the sexual innuendos implied in her speech. Martha's pun, 'where I live", mockingly hints at her own genitals. Another reference to Martha's sensual dominance is made when Martha plots to fluster George and provokes his jealousy upon attempting to copulate with Nick:

MARTHA: We're going to amuse ourselves, George.

GEORGE: [not looking up]: Unh-hunh. That's nice.

MARTHA: You might not like it.

MARTHA: I'm entertaining. I'm entertaining one of the guests. I'm necking with one of the guests.

GEORGE [seemingly relaxed and preoccupied, never looking]: oh that's nice. Which one?

MARTHA: I said I was necking with one of the guests (p.90-91).

On the other hand, Lewis (1964) thinks that the uncontrolled instincts of the id and Martha's libidinous energy that seeks an outlet through sex are the motives behind her sexual aberration. Therefore, she gratifies her sexual needs through 
members of university regardless of social norms or ethics. Lewis (1964) describes Martha as:

The courtesan of the campus, but she is also a woman of tremendous energy who is unfulfilled. Promiscuous sex is an outlet for Martha as Mother Earth, comfort to all men, but a deformed Cybel, whose body seeks pleasure, but will never bear a child. Unable to create, she destroys (p.35-36).

Hence, Martha acts two roles: the pre-oedipal phallic mother and the self-destructive and castrated woman who does not only destroy herself but also others (Gilchrist, 2011). Subscribing to this idea, Kelly (1990) holds the view that Martha's "'personality is destructive and perverted in the moral and social sense. It contributes to the destruction of her marital life and the disintegration of social ties by its perverse anomalous behaviour" (p.373). In truth, Martha's deviant behaviour and infidelity are just reflections of the hopeless struggle between the libidinal demands of the id that seeks pleasure satisfaction as well as liberation and the social constraints of the superego which strives for perfection. Furthermore, Martha's sexual behaviour reflects the unresolved Electra Complex at the phallic-oedipal phase that is caused by the repressed sexual desires she has had for her daddy. Freud (as cited in LoPiccolo and Heiman, 1978) sees sexual behaviour as "the primary reflection of unresolved intrapsychic conflicts" (p.67).

To fend off anxiety, Martha keeps her unresolved instinctual desires for her father stifled in the unconscious and expresses them only through promiscuity. Martha's repression is used as a defence against the anxieties arising from the dissatisfaction of the suppressed desires. The defence mechanism of repression, here, functions as a temporary solution for the internal conflict between the irresistible drives of the id, the superego, performing the critical and moralizing role, and the demands of the ego which attempts to thwart the id's supremacy. Freud, (1957) argues that the "repression proceeds from the self-respect of the ego" and adds that "libidinal instinctual impulses undergo. repression if they come into conflict with the subject's cultural and ethical ideas.' The function of the ego is to inhibit the unacceptable desires of the id from materializing (p.93). However, Martha's repression of sexual impulses does not mean that her urges are gone, but the libidinal drives of the id remain unsatisfied which results in her sexual perversity and aggressiveness.

\section{CONCLUSION}

According to Freud (1953), the individual is captured by the events of his childhood throughout his/her whole life and the unpleasant experiences a person has undergone in early life continue to influence his/her behaviour in later life. Martha suffers from a painful childhood and repressed sexual desires because of her mother's death and the rejection as well as abandonment of her father. During the phallic phase of psychosexual development, Martha had an excessive erotic desire for her father and felt penis envy. Because she fails to negotiate successfully with this stage, Martha is stuck in the phallic phase, which renders her a phallic character. As a result, she is plagued by Electra Complex. The phallic-fix- ation influences the psychosexual development of Martha's personality and delay her sexual and emotional maturity. Though in her fifties, Martha is still fascinated with her father and attempts to earn his respect and love. She regularly keeps on looking for that father figure in her marriage and other extramarital relationships in order to satisfy her desire for her father and compensate for the phallic loss.

Many critics have recognized the presence of psychological aspects in Edward Albee's Who's Afraid of Virginia Woolf?, but few have done little more than mention in passing or concentrate on some psychoanalytic concepts, neglecting many others. By studying Martha's personality psychoanalytically, I attempt not only to develop further the insights provided by other studies, but I also try to introduce new ideas and concepts. The Freudian psychoanalytic reading of Martha's character can help to understand the psychological dimensions of human personality and make the reader aware of the unconscious psychological motives lying behind perverse and unacceptable behaviour. Introducing the character of Martha as a case study, this research illuminates the way for the therapists and psychoanalysts and helps them in diagnosing and treating people who are emotionally disturbed or psychologically damaged.

\section{REFERENCES}

Albee, E. (1962). Who's afraid of Virginia Woolf? London: Vintage Books.

Blum, H. P. (1969). A psychoanalytic view of who's afraid of Virginia Woolf? Journal of American Psychoanalytic Association 17(3), 888-903. https://doi. org/10.1177/000306516901700311

Davis, W. A. (1994). Get the guests: Psychoanalysis, modern American drama and the audience. Madison: University of Wisconsin Press.

Dobie, A.B. (2011). Theory into practice: An introduction to literary criticism. USA: Wadsworth, Cengage Learning.

Dukore, B. F. (1965). A warp in Albee's Woolf. The Southern Speech Journal, 30(3), 261-268. doi: 10.1080/10417946509371784.

Eby, C. V. (2007). Fun and games with George and Nick: Competitive masculinity in who's afraid of Virginia Woolf? Modern Drama, 50(4), 601-619. doi: 10.1353/ mdr.0.0005.

Falsafi, P., Khorashadb, S., \& Abedin, A. (2011). Psychological analysis of the movie "who's afraid of Virginia Woolf?" by using Jungian archetypes. Procedia-Social and Behavioral Sciences, 30, 999-1002. www.sciencedirect.com.

Feist, J., \& Feist, G. J. (2009). Theories of personality. ( $7^{\text {th }}$ ed.). USA: The McGraw-Hill Companies, Inc.

Freud, S. (1919). The uncanny. In Strachey, J. (Ed.). The Standard Edition of the Complete Psychological Works of Sigmund Freud. London: The Hogarth Press.

Freud, S. (1953). Three essays on the theory of sexuality. In Strachey, J. (Ed.), The Standard Edition of the Complete Psychological Works of Sigmund Freud (Vol. 7, pp. 130-243). London: The Hogarth Press. (Original work published 1905). 
Freud, S. (1957). On narcissism: An introduction. In Strachey, J. (Ed.), The Standard Edition of the Complete Psychological Works of Sigmund Freud (Vol. 14, pp. 67-104). London: The Hogarth Press. (Original work published 1914).

Freud, S. (1963a). Introductory lectures on psychoanalysis. In Strachey, J. (Ed.), The Standard Edition of the Complete Psychological Works of Sigmund Freud (Vols. 15 \&16). (Original work published 1917).

Freud, S. (1963b). Some psychological consequences of the anatomical distinction between the sexes. In Philip Rieff (Ed.), Sexuality and the Psychology of Love (pp.183-193). New York: Macmillan. (Original work published 1925).

Freud, S. (1964). New introductory lectures on psychoanalysis. In Strachey, J. (Ed.), The Standard Edition of the Complete Psychological Works of Sigmund Freud (Vol. 22). (Original work published 1933).

Gilchrist, J. (2011). "Right at the meat of things": Virginia Woolf in who's afraid of Virginia Woolf? Women's Studies: An Interdisciplinary Journal, 40(7), 853-872. doi: 10.1080/00497878.2011.603609.

Gross, R. F. (2009). Melancholia-Machine: Perversity and loss in "the play about the baby." Hungarian Journal of English and American Studies, 15(1), 121-133. http:// www.jstor.org/stable/41274460.

Hauge, K. (2009). Interpreted identities- exploring the development of (male) homosexual presentation in American drama (Master thesis). https://www.duo.uio.no/bitstream/handle/./HAUGE_MASTER.pdf.

Hayman, A. (2013). What do our terms mean?: Explorations using psychoanalytic theories and concepts. London: Karnac Books Ltd.

Kelly, K. E. (1990). Review of who's afraid of Virginia Woolf? by Edward Albee. Theatre Journal, 42 (3), 372373. http://www.jstor.org/stable/3208087.

Kernberg, O. (2004). Contemporary controversies in psychoanalytic theory, techniques, and their applications. New haven and London: Yale university press.

Kernberg, O. (2012). A contemporary reading of ' On narcissism.” In Sandler, J., Person, E., \& Fonagy, P. (Eds.),
Freud's 'On Narcissism: An Introduction" (pp.131148). London: Karnac Books Ltd.

Kohut, H. (1977). The restoration of the self. Chicago and London: The University of Chicago Press.

Lewis, A. (1964). The fun and games of Edward Albee. Educational Theatre Journal, 16(1), 29-39. http://www.jstor. org/stable/3204375.

Linda, H. B.(1987). Infertility as boundary ambiguity: One theoretical perspective. Fam Proc, (26),359-372.

LoPiccolo, J. and Heiman, J. The role of cultural values in the prevention and treatment of sexual problems. (1978). In Qualls, C.B., Wincze,G.B. and Barlow, D. H. (Eds.), The prevention of sexual disorders: Issues and approaches (pp.43-71). New York: Plenum Press.

Malarvizhi, K. (2013). Marriage: An illusive reality in Albee's Who's Afraid of Virginia Woolf?. Lapis Lazuli -An International Literary Journal, 3(2), 122-127. http://pintersociety.com/vol-3-no-2autumn-2013

Marković, Z. (2000). Psychoanalytic conceptions of marriage and marital relationships. The scientific journal Facta Universitatis, 2 (7): 379-389. facta.junis.ni.ac.rs/ pas/pas2000/pas2000-08.pdf.

McCarthy, G. (1987). Edward Albee. London: Macmillan Publishers.

Paolucci, A. (1986). Exorcisms: who's afraid of Virginia Woolf? In Philip C. Kolin and J. Madison Davis (Eds.). Critical Essays on Edward Albee (151-162). Boston: G.K. Hall.

Post, R. M. (1969). Cognitive dissonance in the plays of Edward Albee. Quarterly Journal of Speech, 55(1), 54-60. doi: 10.1080/00335636909382928.

Prugh, S. L. (2014). Hallucinatory Figures in Modern American Drama (Master thesis). http://scholar.colorado.edu/ thtr_gradetds/29.

Weales, G. (1975). Edward Albee: Don't make waves. In Bigsby, C. W. E. (Ed.), A Collection of Critical Essays (p.10-22). New Jersey: Prentice-Hall, Inc.

Wolfe, P. (1965). The social theater of Edward Albee. Prairie Schooner, 39(3), 248-62. http://www.jstor.org/stable/40628342. 